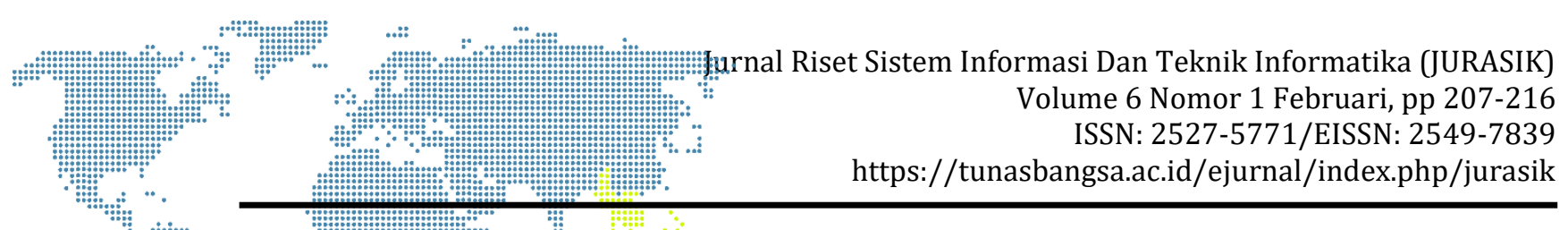

\title{
Analisís Metode SMART Rekrutmen Guru Baru TK/Paud Lestari Di Kabupaten Simalungun
}

\author{
Nadillah Dwi Putrii", Irfan Sudahri Damanik ${ }^{2}$, Eka Irawan ${ }^{3}$ \\ ${ }^{1}$ Mahasiswa STIKOM Tunas Bangsa, Pematangsiantar, Sumatera Utara, Indonesia \\ 2,35TIKOM Tunas Bangsa, Pematangsiantar, Sumatera Utara, Indonesia \\ Jln. Sudirman Blok A No. 1-3 Pematangsiantar, Sumatera Utara \\ 1Debbydinny@gmail.com,2irfansudahri@stikomtunasbangsa.com, \\ 3eka.irawan@amiktunasbangsa.ac.id
}

\begin{abstract}
This research is based on the background of the observations and experiences of researchers, that the system of recruitment of new teachers who are currently running in TK / PAUD LESTARI is still not optimal because they are still doing manual and not computerized methods. As a result, it will slow down the work time of the school in making decisions, searching, inputting, updating, the previous recruitment data of the previous period will also be difficult and require a long time, and the security of data recruitment is also not guaranteed. This study uses a quantitative research approach with the subject of new teacher recruitment research for TK / PAUD LESTARI. Research is carried out in the System Development Life Cycle (SDLC) which is a life cycle or methodology in system development. The conclusion of the results of this study is through the cycle of the System Development Life Cycle (SDLC) which is a life cycle or methodology in developing the system to be even better. Based on the conclusions of the results of this study, it was recommended: the aim of the researchers to conduct this research was to design and create a "New Teacher Recruitment Decision Support System in TK / PAUD LESTARI in Simalungun Regency" in order to facilitate the school in inputting, updating, searching and securing recruitment data.
\end{abstract}

Keywords: SPK, Teacher Recruitment, SMART Method

\begin{abstract}
Abstrak
Penelitian ini di latar belakangi hasil pengamatan dan pengalaman peneliti, bahwa sistem rekrutmen guru baru yang sedang berjalan di TK/PAUD LESTARI masih kurang maksimal sebab masih melakukan cara yang manual dan belum terkomputerisasi. Akibatnya akan memperlambat waktu kerja pihak sekolah dalam pengambilan keputusan, pencarian, penginputan, pembaruan, data rekrutmen lama periode sebelumnya juga akan sulit dan membutuhkan waktu lama, dan keamanan data rekrutmen juga kurang terjamin. Penelitian ini menggunakan pendekatan penelitian kuantitatif dengan subyek penelitian rekrutmen guru baru TK/PAUD LESTARI. Penelitian di lakukukan dalam System Development Life Cycle (SDLC) yang merupakan suatu siklus hidup atau metodelogi dalam pengembangan sistem. Kesimpulan hasil penelitian ini adalah melalui siklus System Development Life Cycle (SDLC) yang merupakan suatu siklus hidup atau metodelogi dalam pengembangan sistem untuk lebih baik lagi. Berdasarkan simpulan hasil penelitian ini di rekomendasikan: tujuan peneliti melakukan penelitian ini adalah merancang dan membuat sebuah "Sistem Pendukung Keputusan Rekrutmen Guru Baru Pada TK/PAUD LESTARI Di Kabupaten Simalungun" agar mempermudah pihak sekolah dalam menginputkan, mengupdate, mencari dan mengamankan data rekrutmen.
\end{abstract}

Kata Kunci: SPK, Rekrutmen Guru, Metode SMART

\section{PENDAHULUAN}

Sistem pendukung keputusan merupakan bagian dari sistem informasi berbasis komputer yang digunakan untuk mendukung pengambilan keputusan dalam suatu organsisasi atau perusahaan. Metode Simple Multi Attribute Rating Technique merupakan suatu metode untuk pengambilan keputusan muti kriteria 


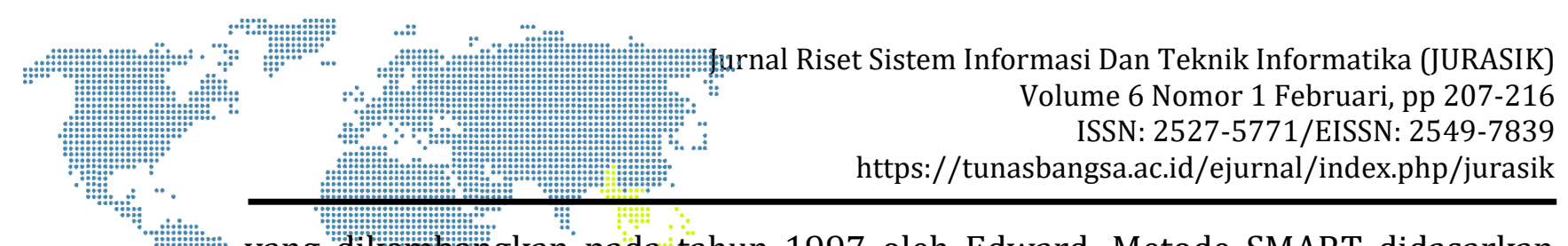

yang dikemembangkan pada tahun 1997 oleh Edward. Metode SMART didasarkan pada teori baliwa setiap alternatif terdiri dari sejumlah kriteria yang memiliki nilai dan setiap kriteria memitilk bobỏt yang menggambarkan seberapa penting nilai dari bobot tersebut dibandingkan dengan kriteria lain. Metode SMART lebih sering digunakan karena kesederhanaannya dalam merespon kebutuhan pembuat keputusan dan menganalisa respon. SMART menggunakan linear additive model untuk meramal nilai setiap alternatif dan metode pengambilan keputusannya fleksibel. Metode ini memberikan pemahaman masalah yang tinggi dan dapat diterima oleh pembuat keputusan [1].

Guru merupakan ujung tombak dalam meningkatkan kualitas pendidikan siswa. Keberhasilan dalam mewujudkan anak didik berkualitas yang menjadi penerus pembangunan bangsa tidak lepas dari sosok guru sebagai tenaga pendidik yang berkualitas, professional, dan relevan dengan kualifikasi tenaga pendidik. Seorang guru melakukan interaksi langsung kepada peserta didik dalam pembelajaran diruang kelas. Secara kuantitas jumlah guru di Indonesia cukup memadai namun secara retribusi dan mutu masih rendah. Disaat ini sulit ditemukan guru yang mampu mengajar peserta didik yang sesuai dengan kualifikasi pendidikan yang maksimal. Sehingga pihak pendidikan merekrut guru yang memiliki pendidikan dan kualitas yang baik.

Rekrutmen guru yaitu proses penerimaan guru baru untuk dapat bekerjasama dalam pembangunan mutu serta prestasi baik dalam suatu sekolah. Guru yang mendaftar sebagai rekrutmen guru baru dengan kualitas yang bersaing seperti Pengalaman Kerja, Pendidikan dan Softskil. Softskill berkaitan dengan dua kompetensi, yaitu kompetensi kepribadian dan sosial. Kompetensi kepribadian berkaitan dengan kecerdasan interpersonal atau mengendalikan diri sendiri. Seperti menjaga Emosi, Tidak Mudah Menyerah, Tidak Mengeluh, Kerja Keras, Sungguh-Sungguh, Ramah, Santun, dan sebagainya. Untuk dapat menjadi guru di TK/PAUD Lestari. Sehingga kualitas yang dimiliki guru membuat pihak pengambil keputusan ambigu dalam menerima guru tersebut di TK/PAUD. Pihak pengambil keputusan memerlukan adanya sistem berbasis komputer yang dapat memberikan rekomendasi pilihan guru yang akan mengajar di TK/PAUD Lestari.

Berdasarkan uraian tersebut banyak sistem berbasis komputer yang dapat menyelesaikan permasalahan tersebut secara kompleks salah satunya metode SMARTER pada sistem pendukung keputusan. Penelitian metode SMART oleh Setyawan (2017) dengan judul "Sistem Pendukung Keputusan Rekrutmen Guru Baru Paud Kopen Kabupaten Kediri Menggunakan Metode SMART" dalam penelitiannya digunakan untuk pemilihan Guru Paud untuk menghasilkan keputusan yang objektif, terkomputerisasi dan mengurangi terjadinya human error. Metode SMART dapat diterapkan dalam pemilihan rekrutmen guru baru TK/PAUD Lestari di Kabupaten Simalungun, sehingga memberikan hasil berupa rekomendasi kepada pihak pengambil keputusan untuk menerima calon guru tersebut. Diharapkan dengan adanya sistem pendukung keputusan menggunakan metode SMART dapat membantu pihak sekolah dalam mengambil keputusan sehingga hasil dari penelitian ini dapat memberikan guru terbaik dengan hasil yang diberikan oleh sistem. 


\section{METODOUOGI PENELITIAN}

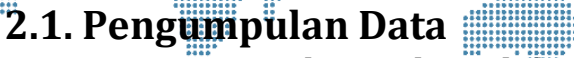

Data yang digunakan dafăm.penelitian adalah data hasil penilaian rekrutmen guru Pada TK PAUD Kabupaten Simalungun. Berikut ini data kriteria yang digunakan pada pemilihan rekrutmen guru TK PAUD Kabupaten Simalungun.

Tabel 1. Daftar Kriteria

\begin{tabular}{|c|l|}
\hline No & \multicolumn{1}{|c|}{ Kriteria } \\
\hline 1 & Pengalaman Kerja (C1) \\
\hline 2 & Pendidikan (C2) \\
\hline 3 & Kemampuan SoftSkill (C3) \\
\hline 4 & Komunikasi (C4) \\
\hline 5 & Disiplin (C5) \\
\hline
\end{tabular}

Sumber: TK/PAUD Lestari Kabupaten Simalungun

Bobot penilaian yang digunakan adalah konsep penalaran fuzzy dimana bobot digunakan untuk dapat melakukan perhitungan dengan metode SMART. Berikut ini data penelitian dapat dilihat pada tabel 2 dibawah ini :

Tabel 2. Data Penelitian

\begin{tabular}{|c|l|l|l|l|c|c|}
\hline Alt & Nama Alternatif & \multicolumn{1}{c|}{ C1 } & C2 & C3 & C4 & C5 \\
\hline A1 & Andi Hamzah & $\begin{array}{l}10 \\
\text { Tahun }\end{array}$ & $\begin{array}{l}\text { S1 } \\
\text { PGTK }\end{array}$ & Baik & Bagus & Bagus \\
\hline A2 & Nova Sari Dewi & 5 Tahun & $\begin{array}{l}\text { D2 } \\
\text { PGTK }\end{array}$ & $\begin{array}{l}\text { Sangat } \\
\text { Baik }\end{array}$ & Bagus & $\begin{array}{l}\text { Tidak } \\
\text { Bagus }\end{array}$ \\
\hline A3 & Nurul Hidayani & 2 Tahun & SMA & Baik & $\begin{array}{l}\text { Tidak } \\
\text { Bagus }\end{array}$ & Bagus \\
\hline A4 & Eliana Nainggolan & $\begin{array}{l}10 \\
\text { Tahun }\end{array}$ & $\begin{array}{l}\text { S1 } \\
\text { PGTK }\end{array}$ & $\begin{array}{l}\text { Kuran } \\
\text { g }\end{array}$ & $\begin{array}{l}\text { Tidak } \\
\text { Bagus }\end{array}$ & Bagus \\
\hline A5 & Nurdiah Safia Rani & 2 Tahun & $\begin{array}{l}\text { D2 } \\
\text { PGTK }\end{array}$ & Baik & Bagus & Bagus \\
\hline A6 & Yola Vazirah & 5 Tahun & SMA & Baik & $\begin{array}{l}\text { Tidak } \\
\text { Bagus }\end{array}$ & Bagus \\
\hline A7 & Rina Ratna Sari & $\begin{array}{l}10 \\
\text { Tahun }\end{array}$ & $\begin{array}{l}\text { D2 } \\
\text { PGTK }\end{array}$ & $\begin{array}{l}\text { Kuran } \\
\text { g }\end{array}$ & Bagus & Bagus \\
\hline
\end{tabular}

\subsection{Metode Penelitian}

\section{a) Sistem Pendukung Keputusan}

Sistem pendukung keputusan adalah suatu sistem informasi spesifik yang ditujukan untuk membantu manajemen dalam mengambil keputusan yang berkaitan dengan persoalan yang bersifat semi terstruktur. Sistem ini memiliki fasillitas untuk menghasilkan berbagai alternatif yang secara interaktif digunakan oleh pemakai [2]. Tujuan Sistem Pendukung Keputusan (SPK) dikemukakan oleh Peter G.W Keen dan Scott Morton (dalam Nofriansyah dan Defit, 2017 : 7) yaitu sebagai berikut : 


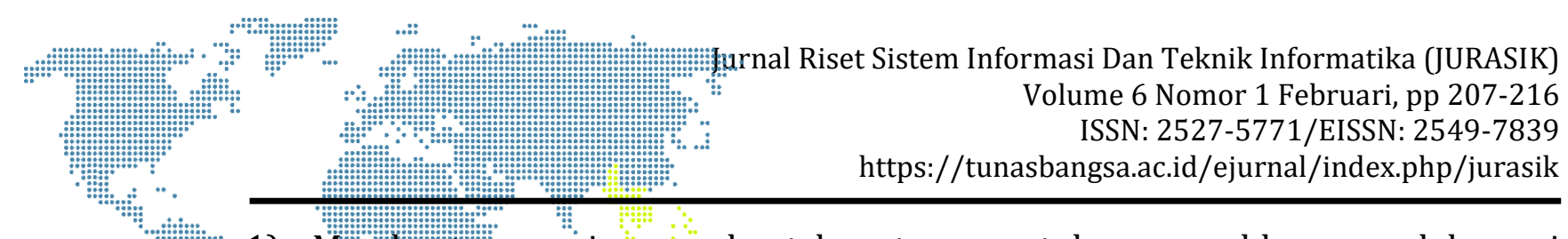

1) Membantu manajer membuat keputusan untuk memecahkan masalah semi terstrumktur.

2) Mendukung penilaian maarajer bukan mencoba untuk menggantikannya.

3) Meningkatkan efektifitâs ....pengambilan keputusan manajer daripada efisiensinya.

\section{b) Metode SMART}

Metode Simple Multi Attribute Rating Technique merupakan suatu metode untuk pengambilan keputusan muti kriteria yang dikembangkan pada tahun 1997 oleh Edward. Metode SMART didasarkan pada teori bahwa setiap alternatif terdiri dari sejumlah kriteria yang memiliki nilai dan setiap kriteria memiliki bobot yang menggambarkan seberapa penting nilai dari bobot tersebut dibandingkan dengan kriteria lain. Metode SMART lebih sering digunakan karena kesederhanaannya dalam merespon kebutuhan pembuat keputusan dan menganalisa respon. SMART menggunakan linear additive model untuk meramal nilai setiap alternatif dan metode pengambilan keputusannya fleksibel. Metode ini memberikan pemahaman masalah yang tinggi dan dapat diterima oleh pembuat keputusan. [3][4]. Adapun langkah-langkah metode SMART adalah sebagai berikut[5]:

a) Tentukan kriteria yang digunakan dalam pemilihan lokasi penyimpanan baru.

b) Tentukan alternatif lokasi penyimpanan baru.

c) Melakukan perangkingan terhadap kedudukan kepentingan kriteria.

d) Memberikan bobot berdasarkan kriteria paling penting dan kriteria paling tidak penting. Kriteria paling penting disetkan dengan bobot nilai 100 dan kriteria paling tidak penting diset dengan bobot nilai 10 .

e) Cari nilai rata-rata bobot kriteria berdasarkan yang paling penting dan paling tidak penting.

f) Berikan bobot kepada setiap alternatif berdasarkan setiap kriteria. Bobot alternatif dalam skala 0-100. Nol sebagai nilai minimum dan 100 sebagai nilai maksimum.

g) Menghitung penilaian/utilitas terhadap setiap alternatif dengan menggunakan rumus (1) [6].

\section{HASIL DAN PEMBAHASAN}

\subsection{Perhitungan Menggunakan Metode K-means}

Berikut ini data penelitian yang diambil sebanyak 7 data calon guru yang sudah diseleksi berdasarkan tahapan-tahapan. Data ini diperoleh dari TK/Paud Lestari Kabupaten Simalungun. Untuk melakukan perhitungan dengan metode SMART, setiap kriteria terdiri dari beberapa sub kriteria dimana proses ini nantinya menjadi penentu dalam proses perangkingan dengan menggunakan metode SMART. proses perhitungan manual akan dilakukan dengan menggunakan metode SMART Berikut ini langkah penyelesaianya:

a) Berikut ini menampilkan normalisasi data kriteria, proses normalisasi bobot berdasarkan rumus seperti yang ditunjukkan pada tabel 3 dibawah ini : 
Hurnal Riset Sistem Informasi Dan Teknik Informatika (JURASIK) Volume 6 Nomor 1 Februari, pp 207-216 ISSN: 2527-5771/EISSN: 2549-7839 https://tunasbangsa.ac.id/ejurnal/index.php/jurasik

Tabel 3. Normalisasi Data Kriteria

\begin{tabular}{|l|c|c|}
\hline \multicolumn{1}{|c|}{ Kriteria } & Bobot Kriteria & Normalisasi Bobot Kriteria \\
\hline Pengaiaman Kerja (C1) & $15 \%$ & $15 / 100=0,15$ \\
\hline Pendidikan (C2) & $25 \%$ & $25 / 100=0,25$ \\
\hline Kemampuan SoftSkill (C3) & $15 \%$ & $15 / 100=0,15$ \\
\hline Teaching Method (C4) & $15 \%$ & $15 / 100=0,15$ \\
\hline Disiplin (C5) & $15 \%$ & $15 / 100=0,15$ \\
\hline
\end{tabular}

b) Berikut ini menampilkan menentukan nilai utility, proses menentukan nilai utility berdasarkan rumus dapat dilihat pada tabel 4 dibawah ini :

Tabel 4. Menentukan Nilai Utility

\begin{tabular}{|l|l|}
\hline \multicolumn{1}{|c|}{ Kriteria } & Bobot Kriteria \\
\hline Pengalaman Kerja (C1) & Lebih besar lebih baik \\
\hline Pendidikan (C2) & Lebih besar lebih baik \\
\hline Kemampuan SoftSkill (C3) & Lebih besar lebih baik \\
\hline Teaching Method (C4) & Lebih besar lebih baik \\
\hline Disiplin (C5) & Lebih besar lebih baik \\
\hline
\end{tabular}

c) Perhitungan menggunakan rumus metode SMART dari Nilai C1 s/d C5 untuk masing- masing alternatif dapat dilihat pada bagian perhitungan dibawah ini:

\section{A. Pengalaman Kerja (C1)}

$\operatorname{Maks}(\mathrm{C} 1)=\operatorname{maks}\{0.9 ; 0.5 ; 0.2 ; 0.9 ; 0.2 ; 0.5 ; 0.9\}=0.9$

$\operatorname{Min}(\mathrm{C} 1)=\min \{0.9 ; 0.5 ; 0.2 ; 0.9 ; 0.2 ; 0.5 ; 0.9\}=0.2$

Sehingga :

$$
\begin{aligned}
& =\left(\frac{0.9-0.2}{0.9-0.2}\right) * 100 \%=1 \\
& =\left(\frac{0.5-0.2}{0.9-0.2}\right) * 100 \%=1 \\
& =\left(\frac{0.2-0.2}{0.9-0.2}\right) * 100 \%=0 \\
& =\left(\frac{0.9-0.2}{0.9-0.2}\right) * 100 \%=1 \\
& =\left(\frac{0.2-0.2}{0.9-0.2}\right) * 100 \%=0 \\
& =\left(\frac{0.5-0.2}{0.9-0.2}\right) * 100 \%=1 \\
& =\left(\frac{0.9-0.2}{0.9-0.2}\right) * 100 \%=0
\end{aligned}
$$

\section{B. Pendidikan (C2)}

Nilai C2 dihitung menggunakan persamaan (3).

Maks (C2) $=$ maks $\{0.9 ; 0.5 ; 0.2 ; 0.9 ; 0.5 ; 0.2 ; 0.5\}=0.9$

Min (C2) $=\min \{0.9 ; 0.5 ; 0.2 ; 0.9 ; 0.5 ; 0.2 ; 0.5\}=0.2$

Sehingga: 


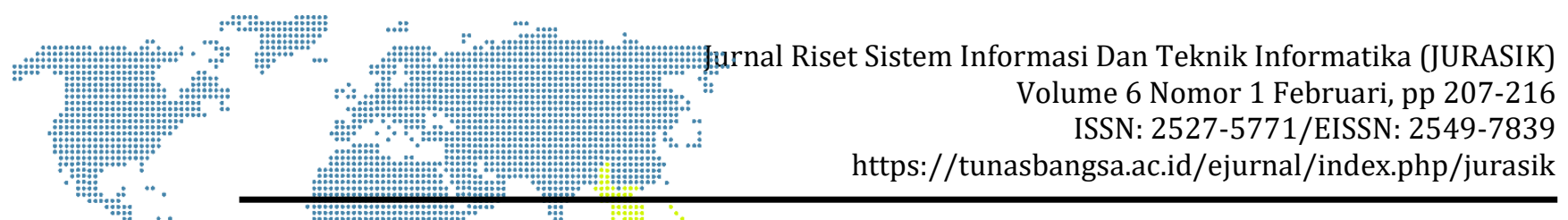

https://tunasbangsa.ac.id/ejurnal/index.php/jurasik

(A1)

(A2)

(A3)

(A4)

$$
\begin{aligned}
& =\left(\frac{0.9-0.2}{0.9-0.2}\right) * 100 \%=1 \\
& =\left(\frac{0.5-0.2}{0.9-0.2}\right) * 1100 \%=\cdot 1 \\
& =\left(\frac{0.2-0.2}{0.9-0.2}\right) * 100 \%=0 \\
& =\left(\frac{0.9-0.2}{0.9-0.2}\right) * 100 \%=1 \\
& =\left(\frac{0.5-0.2}{0.9-0.2}\right) * 100 \%=1 \\
& =\left(\frac{0.2-0.2}{0.9-0.2}\right) * 100 \%=0 \\
& =\left(\frac{0.5-0.2}{0.9-0.2}\right) * 100 \%=1
\end{aligned}
$$

\section{Kemampuan SoftSkill (C3)}

Nilai C3 dihitung menggunakan persamaan (3).

Maks $(\mathrm{C} 3)=\operatorname{maks}\{0.7 ; 0.9 ; 0.7 ; 0.2 ; 0.7 ; 0.7 ; 0.2\}=0.9$

$\operatorname{Min}(\mathrm{C} 3)=\min \{0.7 ; 0.9 ; 0.7 ; 0.2 ; 0.7 ; 0.7 ; 0.2\}=0.2$

Sehingga:

$$
\begin{aligned}
& =\left(\frac{0.7-0.2}{0.9-0.2}\right) * 100 \%=1 \\
& =\left(\frac{0.9-0.2}{0.9-0.2}\right) * 100 \%=1 \\
& =\left(\frac{0.7-0.2}{0.9-0.2}\right) * 100 \%=1 \\
& =\left(\frac{0.2-0.2}{0.9-0.2}\right) * 100 \%=0 \\
& =\left(\frac{0.7-0.2}{0.9-0.2}\right) * 100 \%=1 \\
& =\left(\frac{0.7-0.2}{0.9-0.2}\right) * 100 \%=1 \\
& =\left(\frac{0.2-0.2}{0.9-0.2}\right) * 100 \%=0
\end{aligned}
$$

\section{Teaching Method (C4)}

Nilai C4 dihitung menggunakan persamaan (3).

Maks $(C 4)=\operatorname{maks}\{0.5 ; 0.5 ; 0.2 ; 0.2 ; 0.5 ; 0.2 ; 0.5\}=0.5$

Min (C4) $=\operatorname{maks}\{0.5 ; 0.5 ; 0.2 ; 0.2 ; 0.5 ; 0.2 ; 0.5\}=0.2$

Sehingga:

$$
\begin{aligned}
& =\left(\frac{0.5-0.2}{0.5-0.2}\right) * 100 \%=1 \\
& =\left(\frac{0.5-0.2}{0.5-0.2}\right) * 100 \%=1 \\
& =\left(\frac{0.2-0.2}{0.5-0.2}\right) * 100 \%=0 \\
& =\left(\frac{0.2-0.2}{0.5-0.2}\right) * 100 \%=0 \\
& =\left(\frac{0.5-0.2}{0.5-0.2}\right) * 100 \%=1 \\
& =\left(\frac{0.2-0.2}{0.5-0.2}\right) * 100 \%=0 \\
& =\left(\frac{0.5-0.2}{0.5-0.2}\right) * 100 \%=1
\end{aligned}
$$




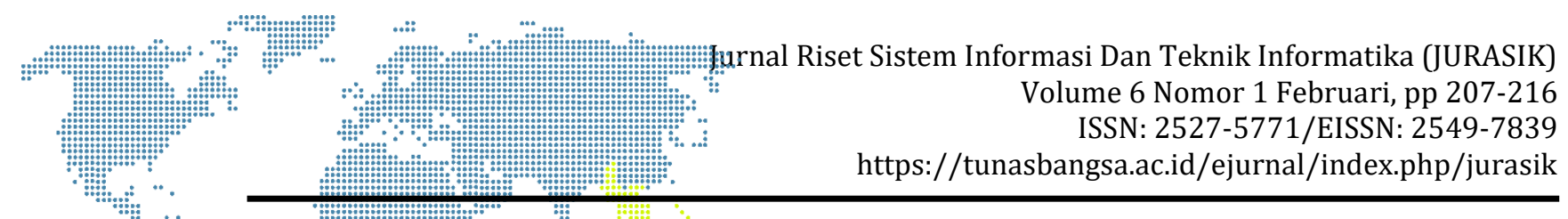

\section{E. Disiplin (C5)}

Nilai C5 dimitung menggunakan persamaan (3).

Maks (C5) =

Min (C5) $=\operatorname{maks}\{0.5 ; 0.2 ; 0.5 ; 0.5 ; 0.5 ; 0.5 ; 0.5\}=0.2$

Sehingga:

$$
\begin{aligned}
& =\left(\frac{0.5-0.2}{0.5-0.2}\right) * 100 \%=1 \\
& =\left(\frac{0.2-0.2}{0.5-0.2}\right) * 100 \%=0 \\
& =\left(\frac{0.5-0.2}{0.5-0.2}\right) * 100 \%=1 \\
& =\left(\frac{0.5-0.2}{0.5-0.2}\right) * 100 \%=1 \\
& =\left(\frac{0.5-0.2}{0.5-0.2}\right) * 100 \%=1 \\
& =\left(\frac{0.5-0.2}{0.5-0.2}\right) * 100 \%=1 \\
& =\left(\frac{0.5-0.2}{0.5-0.2}\right) * 100 \%=1
\end{aligned}
$$

Berdasarkan perhitungan Matriks Perhitungan Nilai Utility Alternatif, maka hasil keseluruhan perhitungan dapat dilihat pada tabel berikut:

Tabel 5. Matriks Perhitungan Nilai Utility Alternatif

\begin{tabular}{|l|c|c|c|c|c|}
\hline \multicolumn{1}{|c|}{ Cluster } & C1 & C2 & C3 & C4 & C5 \\
\hline Andi Hamzah & 1 & 1 & 1 & 1 & 1 \\
\hline Nova Sari Dewi & 1 & 1 & 1 & 1 & 0 \\
\hline Nurul Hidayani & 0 & 0 & 1 & 0 & 1 \\
\hline Eliana Nainggolan & 1 & 1 & 0 & 0 & 1 \\
\hline Nurdiah Safia Rani & 0 & 1 & 1 & 1 & 1 \\
\hline Yola Vazirah & 1 & 0 & 1 & 0 & 1 \\
\hline Rina Ratna Sari & 0 & 1 & 0 & 1 & 1 \\
\hline
\end{tabular}

d) Berikut ini menjelaskan mengenai perhitungan untuk Menentukan nilai akhir menggunakan rumus yang sudah penulis buat, dapat dilihat pada penjelasan dibawah ini :

\section{1) Pengalaman Kerja (C1)}
(A1)
(A2)
$=1 * 0,15=0,15$
(A3)
$=1 * 0,15=0.15$
(A4)
$=0 * 0,15=0$
(A5)
$=1 * 0,15=0.15$
(A6)
$=0 * 0,15=0$
(A7)
$=1 * 0,15=0.15$$$
=0 * 0,15=0
$$

2) Pendidikan (C2)
(A1)
(A2)
$=1 * 0,25=0,25$
(A3)
$=1 * 0,25=0,25$
(A4)
$=0 * 0,25=0$
$=1 * 0,25=0,25$ 


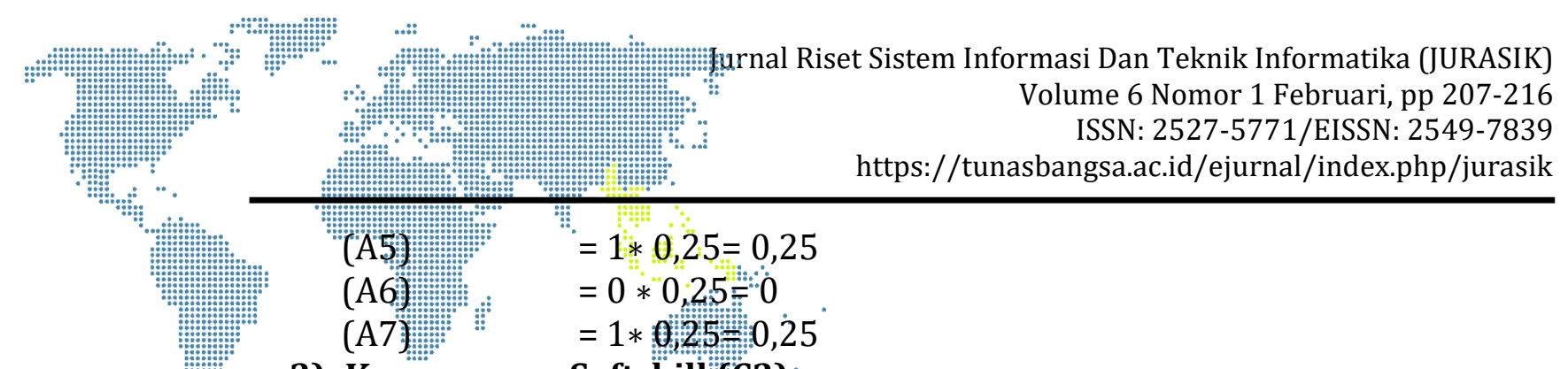

3) Kemampuan Softskill (C3).
(A1)
$=1 * 0,15=0,15$
(A2)
$=1 * 0,15=0,15$
(A3)
(A4)
$=1 * 0,15=0,15$
(A5)
$=0 * 0,15=0$
(A6)
$=1 * 0,15=0,15$
(A7)
$=1 * 0,15=0,15$
$=0 * 0,15=0$

4) Teaching Method (C4)
(A1)
(A2)
$=1 * 0,15=0,15$
(A3)
$=1 * 0,15=0,15$
(A4)
$=0 * 0,15=0$
(A5)
$=0 * 0,15=0$
(A6)
$=1 * 0,15=0,15$
(A7)
$=0 * 0,15=0$

5) Disiplin (C5)

\begin{tabular}{|c|c|}
\hline (A1) & $=1 * 0,15=0,15$ \\
\hline (A2) & $=0 * 0,15=0$ \\
\hline (A3) & $=1 * 0,15=0,15$ \\
\hline (A4) & $=1 * 0,15=0,15$ \\
\hline (A5) & $=1 * 0,15=0,15$ \\
\hline CA6 & $=1 * 0,15=0,15$ \\
\hline & $=1 * 0,15=0,15$ \\
\hline
\end{tabular}

e) Sehingga setelah perhitungan telah dilakukan maka penulis mendapatkan hasil dari setiap cluster dapat dilihat pada tabel seperti dibawah ini:

Tabel 6. Perhitungan Nilai Akhir

\begin{tabular}{|l|c|c|c|c|c|c|}
\hline \multicolumn{1}{|c|}{ Cluster } & C1 & C2 & C3 & C4 & C5 & Nilai Akhir \\
\hline Andi Hamzah & 0,15 & 0.25 & 0,15 & 0,15 & 0,15 & 0.85 \\
\hline Nova Sari Dewi & 0,15 & 0.25 & 0,15 & 0,15 & 0 & 0,70 \\
\hline Nurul Hidayani & 0 & 0 & 0,15 & 0 & 0,15 & 0,30 \\
\hline Eliana Nainggolan & 0,15 & 0.25 & 0 & 0 & 0,15 & 0.55 \\
\hline Nurdiah Safia Rani & 0 & 0.25 & 0,15 & 0,15 & 0,15 & 0.70 \\
\hline Yola Vazirah & 0,15 & 0 & 0,15 & 0 & 0,15 & 0.45 \\
\hline Rina Ratna Sari & 0,15 & 0.25 & 0 & 0,15 & 0,15 & 0.70 \\
\hline
\end{tabular}

Berdasarkan tabel 6, untuk memperoleh hasil akhir, maka nilai setiap alternatif dijumlahkan. Berdasarkan hasil akhir dapat disimpulkan bahwa Andi Hamzah yang menjadi rekomendasi sebagai Calon Guru TK/Paud Lestari Di Kabupaten Simalungun yang akan direkomendasikan dengan nilai rank tertinggi menggunakan metode SMART Sebesar 0.85. 


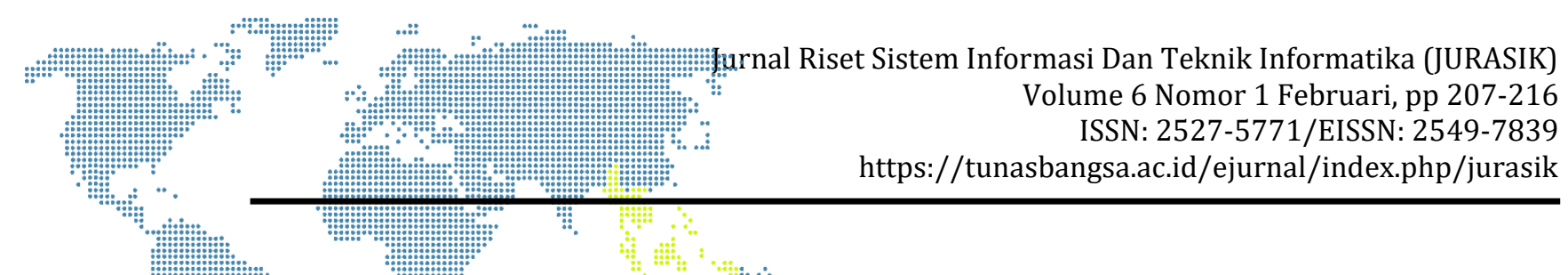

\subsection{Penbahasan}

Pada Sistem Pendukiding Keputusan Rekrutmen Guru Baru TK/Paud Lestari Di Kabupaten Simalungun menggunakan algoritma baik perhitungan secara manual maupun secara komputerisasi menunjukkan hasil yang sama, yaitu alternatif $\mathrm{A}_{1}$ merupakan alternatif terbaik. Berikut adalah hasil yang diperoleh menggunakan komputerisasi dengan aplikasi berbasis web. Tampilan hasil perhitungan dapat dilihat pada gambar 1 . berikut.

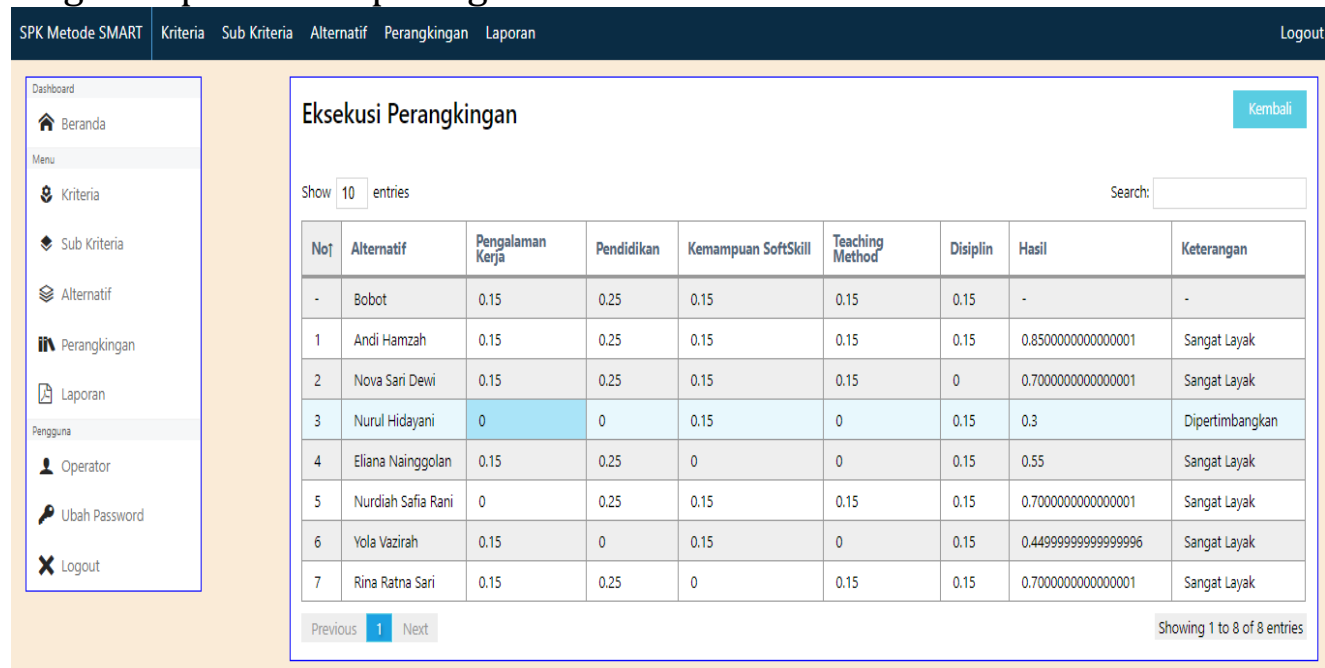

Gambar 1. Tampilan Hasil Perhitungan Algoritma SMART

\section{SIMPULAN}

Kesimpulan yang didapat dari penelitian adalah:

a) Sistem Pendukung Keputusan Rekrutmen Guru Baru TK/Paud Lestari Di Kabupaten Simalungun Menggunakan Metode SMART dapat digunakan sebagai proses pengambilan keputusan dalam rekomendasi Guru Pada TK/PAUD Lestari.

b) Penelitian ini menggunakan 7 alternatif yaitu Andi Hamzah (A1), Nova Sari Dewi (A2), Nuru Hidayani(A3), Eliana Nainggolan(A4), Nurdiah Safia Rani(A5), Yola Vazirah(A6) , Rina Ratna Sari(A7) dan 5 kriteria yaitu untuk kriteria nya adalah Pengalaman Kerja, Pendidikan, Kemampuan Softskill, Komunikasi, Disiplin.

c) Metode SMART merupakan salah satu metode pengambilan keputusan yang mendukung pengambilan keputusan dengan banyak kriteria.

d) Berdasarkan hasil perhitungan manual dan sistem, diperoleh hasil yang perangkingan yang memiliki rank tertinggi dan berhak direkomendasikan sebagai guru TK/PAUD adalah Andi Hamzah dari alternatif 1 dengan nilai hasil perhitungan metode SMART dengan hasil akhir 0.85 . 


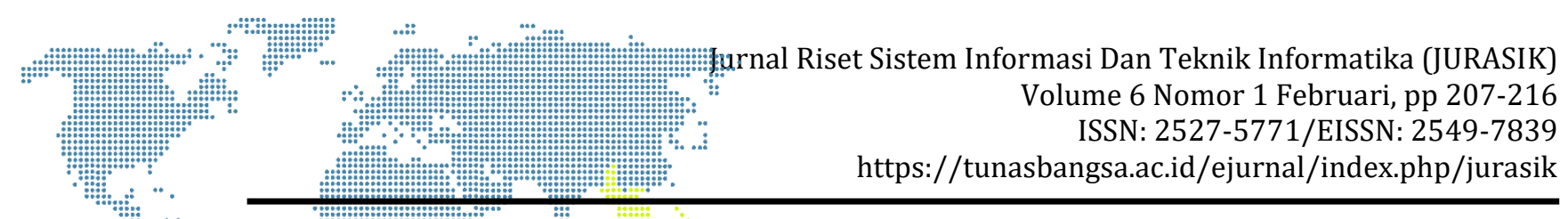

\section{DAFTAR PUSTAKA}

11] A. Setyawan, "Simki-Economic Vol. 01 No. 03 Tahun 2017 Issn : Bbbb-Bbbb," SimkiEconomié, Vol. 01, No 03 P. P. 1-14, 2017.

[2] R. Umar, A. Fadlil, And y." A. Dahlan, "Khazanah Informatika Sistem Pendukung Keputusan Dengan Metode Âhp Untuk Penilaian Kompetensi Soft Skill Karyawan," Pp. 27-34, 2018.

[3] M. Safrizal, "Sistem Pendukung Keputusan Pemilihan Karyawan Teladan Dengan Metode Smart ( Simple Multi Attribute Rating Technique )," Vol. 1, No. 2, Pp. 25-29, 2015.

[4] Y. Purnamasari, T. H. Pudjiantoro, And D. Nursantika, "Sistem Penilaian Kinerja Dosen Teladan Menggunakan Metode Simple Multy Attribute Rating Technique ( Smart ) Abstrak - Pemilihan Dosen Teladan Dilakukan Dengan Cara Memilih Alternatif Dosen Yang Memenuhi Syarat Berdasarkan Kriteria Yang Sudah Ditentukan.."

[5] D. Universitas And B. Darma, "Kelayakan Bisnis Menerapkan Simple Multi Attribute Rating Technique ( Smart)," Pp. 113-124.

[6] Suryanto And M. Safrizal, "Sistem Pendukung Keputusan Pemilihan Karyawan Teladan Dengan Metode Smart (Simple Multi Attribute Rating Technique)," J. Coreit, Vol. 1, No. 2, Pp. 2460-738, 2015. 